\title{
Correction to: Buddy biking: a user study on social collaboration in a virtual reality exergame for rehabilitation
}

\author{
Emil Rosenlund Høeg ${ }^{1}$ (D ) Jon Ram Bruun-Pedersen ${ }^{1}$ (10 $\cdot$ Shannon Cheary $^{3} \cdot$ Lars Koreska Andersen $^{1} \cdot$ Razvan Paisa $^{1}$. \\ Stefania Serafin ${ }^{1}$ (i) $\cdot$ Belinda Lange ${ }^{2}$ (i)
}

Published online: 29 August 2021

(c) Springer-Verlag London Ltd., part of Springer Nature 2021

\section{Correction to: Virtual Reality https://doi.org/10.1007/s10055-021-00544-z}

The article "Buddy biking: a user study on social collaboration in a virtual reality exergame for rehabilitation", written by Emil Rosenlund Høeg et al., was originally published online on 27th, July 2021, without Open Access.

After publication, the author decided to opt for Open Choice and to make the article an Open Access publication. Therefore, the copyright of the article has been changed to (C) The Author(s) 2021, and the article is forthwith distributed under the terms of the Creative Commons Attribution 4.0 International License, which permits use, sharing, adaptation, distribution and reproduction in any medium or format, as long as you give appropriate credit to the original author(s) and the source, provide a link to the Creative Commons license, and indicate if changes were made. The images or other third-party material in this article is included in the article's creative commons license, unless indicated otherwise in a credit line to the material. If material is not included in the article's creative commons license and your intended use is not permitted by statutory regulation or exceeds the permitted use, you will need to obtain permission directly from the copyright holder. To view a copy of this license, visit http://creativecommons.org/licen ses/by/4.0.

The original article can be found online at https://doi.org/10.1007/ s10055-021-00544-z.

Emil Rosenlund Høeg

erh@create.aau.dk

1 Department of Architecture, Design, and Media Technology, Aalborg University, Copenhagen, Denmark

2 Caring Futures Institute College of Nursing and Health, Science, Flinders University, Adelaide, Australia

3 Division of Rehabilitation, Aged Care and Palliative Care, Flinders Medical Centre, Adelaide, Australia
Publisher's Note Springer Nature remains neutral with regard to jurisdictional claims in published maps and institutional affiliations. 